\title{
Transgenic mice overproducing islet amyloid polypeptide have increased insulin storage and secretion in vitro
}

\author{
C. B. Verchere ${ }^{1,2}$, D.A.D'Alessio ${ }^{1}$, R. D.Palmiter ${ }^{3}$, S. E. Kahn ${ }^{1,2}$ \\ ${ }^{1}$ Division of Metabolism, Endocrinology and Nutrition, Department of Medicine, University of Washington, Seattle, Washington, \\ USA \\ ${ }^{2}$ Veterans Affairs Medical Center, Seattle, Washington, USA \\ ${ }^{3}$ Howard Hughes Medical Institute, University of Washington, Seattle, Washington, USA
}

\begin{abstract}
Summary To determine whether chronic overproduction of islet amyloid polypeptide alters beta-cell function, we studied a line of transgenic mice which overexpress islet amyloid polypeptide in their beta-cells. At 3 months of age, these transgenic mice had greater pancreatic content of both islet amyloid polypeptide and insulin. Further, basal and glucose-stimulated secretion of both islet amyloid polypeptide and insulin were also elevated in the perfused pancreas of the transgenic animals. These findings demonstrate that chronic over-
\end{abstract}

production and secretion of islet amyloid polypeptide are associated with increased insulin storage and enhanced secretion of insulin in vitro. This increase in insulin storage and secretion may be due to a direct effect of islet amyloid polypeptide on the beta-cell or a betacell adaptation to islet amyloid polypeptide-induced insulin resistance. [Diabetologia (1994) 37: 725-728]

Key words Insulin, islet amyloid polypeptide, pancreas, secretion.
The function of the beta-cell peptide IAPP (also called amylin) is not known. Acute administration of IAPP has been shown to inhibit both insulin secretion from the beta-cell and insulin action on muscle, although some investigators have failed to find an effect of IAPP on either insulin secretion or action $[1,2]$. Since both impaired insulin secretion and peripheral insulin resistance are hallmarks of NIDDM, it has been hypothesized that excess production and secretion of IAPP might play a role in the pathogenesis of this disease. To evaluate the potential role of long-term production of excess IAPP, we studied a line of transgenic mice which overexpress IAPP in their pancreatic beta-cells. We hypothesized that long-term excess IAPP might influence beta-cell synthesis and

Received: 7 January 1994

and in revised form: 3 March 1994

Corresponding author: Dr. C. B. Verchere, Veterans Affairs Medical Center (151L), Division of Endocrinology and Metabolism, 1660 South Columbian Way, Seattle, WA 98108, USA

Abbreviations: IAPP, Islet amyloid polypeptide; bp, base pair; TFA, trifluoroacetic acid; IRI, immunoreactive insulin; SLI, somatostatin-like immunoreactivity; IAPP-LI, IAPP-like immunoreactivity. secretion. Therefore, in this study, we measured pancreatic insulin and IAPP content and secretion from the perfused pancreas of these transgenic mice.

\section{Materials and methods}

Transgenic mice. Transgenic mice were bred at the Howard Hughes Medical Institute, University of Washington. A $676 \mathrm{bp}$ fragment of cDNA encoding the entire human proIAPP sequence (donated by Dr. D. Steiner, University of Chicago) was fused between a $600 \mathrm{bp}$ fragment of the rat insulin II gene promoter and a fragment containing the $3^{\prime}$ untranslated region of the mouse MHC E $\alpha$ class II gene encoding the polyadenylation sequence. This construct was microinjected into the pronuclei of fertilized mouse eggs (C57 BL6 $\times$ DBA2), which were then implanted into the oviducts of pseudopregnant Swiss Webster female mice. Three transgenic founder animals were produced which passed the hIAPP transgene on to their progeny when mated with normal $\mathrm{C} 57 \mathrm{BL} 6 \times \mathrm{DBA} 2$ mice. The offspring of these mice were examined for expression of the transgenic message in their pancreas by Northern blot analysis of pancreatic RNA. One line (RIP hIAPP 25-3) which expresses human proIAPP mRNA in their pancreas was used in the present study.

Pancreatic extracts. Frozen pancreas samples from six pairs of non-transgenic and heterozygous transgenic mice (approximately 3 months old) were homogenized in $2 \mathrm{~mol} / \mathrm{lacetic}$ acid ( $3-5 \mathrm{ml}$ ) 

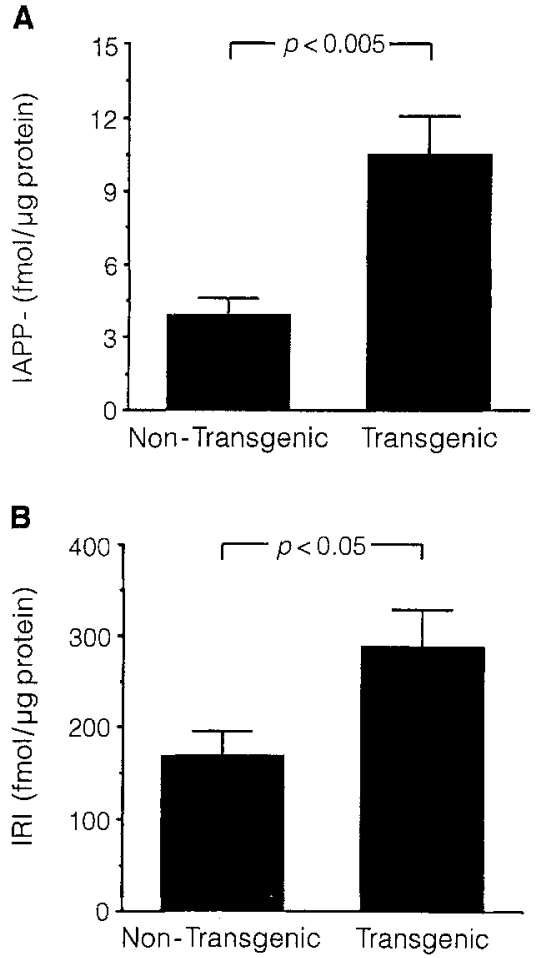

Fig. 1 A, B. Pancreatic content of (A) IAPP-LI and (B) IRI from six pairs of transgenic and non-transgenic mice. Data are mean \pm SEM

A

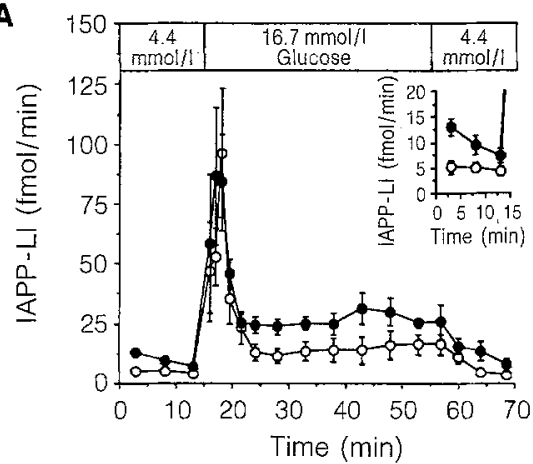

B

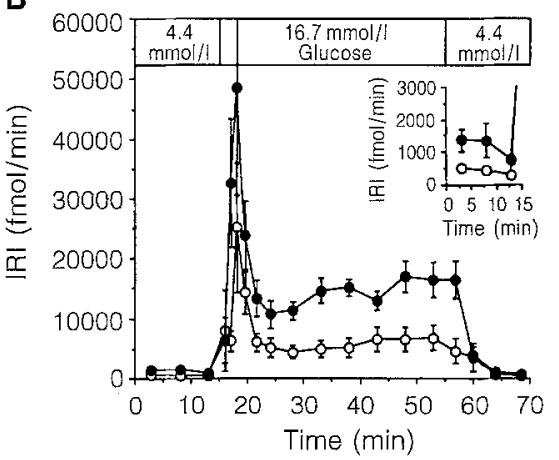

Fig. 2 A, B. Secretion of (A) IAPP-LI and (B) IRI from the isolated, perfused pancreas of five pairs of transgenic $(-)$ ) and non-transgenic $(0-0)$ mice in response to $16.7 \mathrm{mmol} / \mathrm{l}$ glucose. Insets: view of (A) IAPP-LI and (B) IRI secretion during basal $(4.4 \mathrm{mmol} / \mathrm{l})$ glucose perfusion. Each point represents the mean \pm SEM and boiled for $15 \mathrm{~min}$. The extract was centrifuged $(3500 \times \mathrm{g}$ for $10 \mathrm{~min}$ ) and the supernatant stored at $-20^{\circ} \mathrm{C}$ until assayed.

Perfused pancreas. Five non-fasted pairs of heterozygous transgenic and non-transgenic mice (approximately 3 months old) were anaesthetized with $80 \mathrm{mg} / \mathrm{kg}$ sodium pentobarbital administered intraperitoneally. The procedure for surgical isolation and vascular perfusion of the mouse pancreas was identical to that for the rat [3], except smaller tubing was used for both the arterial (PE50 tubing; Cole-Parmer, Parsippany, N.J., USA) and portal venous (PE90 tubing) cannulae. Flow rate of the perfusate was $1 \mathrm{ml} / \mathrm{min}$.

Fractions of portal venous effluent were collected at 1-min intervals in polystyrene test tubes containing $25 \mu \mathrm{l}$ acetic acid $(10 \mathrm{~mol} / \mathrm{l})$ to inhibit protease activity. Effluent samples were extracted on Bond Elut C18/OH columns (Varian, Harbor City, Calif., USA) as follows. Samples $(0.75-3.0 \mathrm{ml})$ were first applied to pre-wet columns; some fractions were pooled prior to applica-

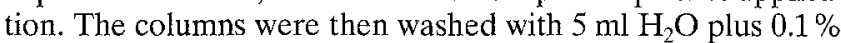
TFA followed by $5 \mathrm{ml} 10 \%$ acetonitrile plus $0.1 \%$ TFA. The peptides were eluted with $3 \mathrm{ml} 60 \%$ acetonitrile plus $0.1 \%$ TFA. The eluates were dried on a Speed Vac Plus (Savant, Farmingdale, N. Y., USA) overnight and stored at $-20^{\circ} \mathrm{C}$ until assay. Recovery of rat IAPP and rat insulin standard added to perfusate and extracted by this technique was $65 \%$ and $94 \%$, respectively.

Peptide measurement. IRI, IAPP-LI, and SLI were all measured using previously described RIA's $[4,5]$. The antiserum (Peninsula; Belmont, Calif., USA) used in the IAPP RIA was raised in rabbits to human IAPP and recognizes rodent and human IAPP on an equimolar basis. Therefore, in this study, IAPP-LI in transgenic mice refers to total (mouse plus human) IAPP immunoreactivity. Pancreatic IRI, IAPP-LI, and SLI content were normalized to pancreatic protein as determined by the Lowry protein assay.

Calculations and statistical analysis. Data are expressed as mean \pm SEM. Hormone output of IAPP-LI (femtomol) and IRI (picomol) were calculated as total area under the curve using the trapezoidal method. Basal secretion was calculated from min 0 to 15 , first phase secretion from min 15 to 20 , second phase secretion from min 20 to 55 , and both (first plus second phase secretion) from min 15 to 55 .

Statistical comparisons between transgenic and non-transgenic groups were performed using the Mann-Whitney U test with $p$ less than 0.05 being considered significant.

\section{Results}

When normalized to pancreatic protein, pancreatic IAPP-LI content in the transgenic mice was nearly three-fold that of non-transgenic animals (Fig. 1 A; $10.5 \pm 1.6$ vs $3.9 \pm 0.7 \mathrm{fmol} / \mu \mathrm{g}$ pancreatic protein; $n=6$ pairs; $p<0.005$ ), indicating that the pancreatic beta-cells of these transgenic mice were overproducing IAPP. Pancreatic IRI content was also significantly higher in the transgenic mice compared to controls (Fig. $1 \mathrm{~B} ; 288 \pm 41$ vs $169 \pm 26 \mathrm{fmol} / \mu \mathrm{g} ; n=6$ pairs; $p<0.05)$. Furthermore, there was a highly significant correlation between pancreatic IAPP-LI and IRI content in the transgenic animals $(r=0.969 ; p=0.001$; $n=6$ ). Thus, pancreatic insulin storage appears to be elevated in mice overproducing IAPP. This increase in 
pancreatic peptide content in the transgenic mice appears to be specific to the beta-cell, since pancreatic SLI content did not differ significantly between transgenic and non-transgenic animals $(2.57 \pm 0.49(n=5)$ vs $1.62 \pm 0.62 \mathrm{fmol} / \mu \mathrm{g}(n=4) ; p>0.1)$, and no significant correlation was found between pancreatic IAPP-LI and SLI content in the transgenic mice $(r=-0.595$; $p>0.4 ; n=4)$.

To determine whether release of IAPP and insulin in the transgenic mice increased in parallel with the increase in pancreatic content of these peptides, we assessed the secretion of IAPP-LI and IRI in response to glucose stimulation using the isolated, perfused pancreas. When beta-cell secretion was stimulated with $16.7 \mathrm{mmol} / \mathrm{l}$ glucose, the total IAPP-LI response was nearly two times greater in the transgenic mice (Fig. $2 \mathrm{~A} ; 1234 \pm 83$ vs $767 \pm 215 \mathrm{fmol} / 40 \mathrm{~min}$; $n=5$ pairs; $p<0.05$ ). This difference in glucose-stimulated IAPP-LI output arose mainly from a difference in second phase glucose-stimulated IAPP-LI release ( $873 \pm 97$ vs $467 \pm 48 \mathrm{fmol} / 35 \mathrm{~min} ; p<0.05$ ), since firstphase glucose-stimulated IAPP-LI output was not significantly different between transgenic and non-transgenic animals ( $361 \pm 61$ vs $300 \pm 68 \mathrm{fmol} / 5 \mathrm{~min} ; p \mathrm{NS}$ ). In the presence of $4.4 \mathrm{mmol} / \mathrm{l}$ glucose, the mean basal output of IAPP-LI in the transgenic mice was also nearly two times that of the control animals (Fig. $2 \mathrm{~A}$ inset; $193 \pm 26$ vs $72 \pm 12 \mathrm{fmol} / 15 \mathrm{~min} ; p<0.05)$. Thus, both basal and glucose-stimulated IAPP-LI secretion are elevated in these transgenic mice in vitro. This increase in IAPP-LI release was not due to a difference in body weight between the two groups of mice (transgenic: $29.2 \pm 0.8 \mathrm{~g}$; non-transgenic: $28.1 \pm 1.0 \mathrm{~g} ; p \mathrm{NS}$ ).

As with IAPP-LI secretion, IRI secretion in the presence of $16.7 \mathrm{mmol} / \mathrm{l}$ glucose was also significantly elevated in the transgenic animals; total IRI output during the $40 \mathrm{~min}$ of glucose stimulation was more than double that of the controls (Fig. 2B; $1152 \pm 330$ vs $416 \pm 93 \mathrm{pmol} / 40 \mathrm{~min} ; p<0.05)$. Again, this difference was mainly due to an elevation of second phase glucose-stimulated IRI secretion $(613 \pm 84$ vs $166 \pm 49 \mathrm{pmol} / 35 \mathrm{~min} ; p<0.05)$. Although first phase IRI output tended to be higher in the transgenic animals, this difference did not achieve statistical significance $(156 \pm 36$ vs $76 \pm 19 \mathrm{pmol} / 5 \mathrm{~min} ; p=0.07)$. Basal (4.4 mmol/1 glucose) IRI output was also significantly elevated in transgenic mice compared to controls (Fig. 2B inset; $17.3 \pm 4.9$ vs $6.2 \pm 1.4 \mathrm{pmol} / 15 \mathrm{~min}$; $p<0.05)$.

\section{Discussion}

In this study, we have demonstrated an increase in both the pancreatic content and the secretion of insulin in vitro in transgenic mice which overproduce and hypersecrete IAPP. These data suggest that long-term production of excess IAPP results in increased in- sulin storage and secretion by the beta-cell, and therefore raise the possibility that IAPP may be a longterm regulator of beta-cell function. Since both basal and glucose-stimulated IAPP secretion were elevated in the transgenic mice in vitro, it is likely that circulating IAPP-LI levels are also elevated in these animals and therefore tissues that may be sensitive to the actions of IAPP (i. e. beta-cell and muscle) have been chronically exposed to high levels of circulating IAPP. Measurement of plasma IAPP-LI levels will be required to confirm this possibility.

A number of different mechanisms can be proposed to explain the increase in insulin storage and secretion observed in the transgenic mice. First, since IAPP has been suggested to cause insulin resistance, it is plausible that the increased pancreatic content and secretion of insulin observed in the transgenic mice described in this study occurred as a result of a beta-cell adaptation to IAPP-induced insulin resistance. During chronic insulin resistance, the pancreas is known to adapt by increasing insulin production and output. This has been clearly shown in rodent models of insulin resistance associated with obesity such as the Zucker rat [6], as well as in humans with insulin resistance [7]. Thus, similar to obese Zucker rats and insulin resistant humans, the transgenic mice in this study had increased insulin secretion under both basal and glucose-stimulated conditions.

An alternative interpretation of these results is that the increased production of IAPP in the transgenic mice alters insulin storage and secretion via a direct effect on the beta-cell. Acute studies in the rat suggest that high concentrations of IAPP may impair insulin secretion [1,2] but not insulin synthesis [8], which would then potentially increase pancreatic insulin content. It is therefore possible that long-term impairment of insulin secretion could lead to increased storage of insulin in the beta-cell. However, this possibility cannot explain our observation of increased insulin secretion from the perfused pancreas of the transgenic mice. Furthermore, this increased insulin release suggests that IAPP is not likely to cause the impaired beta-cell function of NIDDM.

Another explanation is that IAPP might directly stimulate beta-cell hyperplasia and/or hypertrophy. While it has been shown that IAPP probably does not influence insulin biosynthesis when administered acutely [8], the long-term effects on beta-cell growth have not been examined. This idea is worthy of further examination because calcitonin gene-related peptide (CGRP), which has $40 \%$ structural homology with IAPP-LI and shares some of its biological activities [1], was recently shown to stimulate endothelial cell growth in culture [9]. Moreover, we have recently demonstrated that a significant proportion of IAPP-LI is released from the beta-cell via the constitutive secretory pathway $[10]$, and it is therefore possible that continuous IAPP release might have a role in the regulation 
of more long-term metabolic processes such as cell growth.

In summary, we have found that overproduction and hypersecretion of IAPP in transgenic mice are associated with increased storage and secretion of insulin in vitro. These changes might arise via a direct effect of IAPP on the islet to stimulate insulin synthesis or enhance beta-cell growth, or alternatively, these changes may arise indirectly, as a beta-cell adaptation to IAPPinduced insulin resistance.

Acknowledgements. The authors thank Dr. D. Porte, Jr. for critical reading of this manuscript, and Ms. M. Abrahamson, Mrs. H. Nguyen, Ms. E. Laschansky, and Ms. R. Vogel for expert technical assistance. This study was supported by the Department of Veterans Affairs and by National Institutes of Health Grants DK-12829, DK-35816 and HD-09172. C. B. V. was supported by a post-doctoral fellowship from the Juvenile Diabetes Foundation International.

\section{References}

1. Cooper GJS, Day AJ, Willis AC, Roberts AN, Reid KBM, Leighton B (1989) Amylin and the amylin gene: structure, function and relationship to islet amyloid and to diabetes mellitus. Biochem Biophys Acta 1014:247-258

2. Westermark P, Johnson KH, O'Brien TD, Betsholtz C (1992) Islet amyloid polypeptide - a novel controversy in diabetes research. Diabetologia 35:297-303
3. Verchere CB, Kwok YN, Brown JC (1993) Inhibitory actions of a somatostatin analog, SMS 201-995, on pancreatic and gastric endocrine secretion. Pharmacology 46: 54-60

4. Kahn SE, Fujimoto WY, D'Alessio DA, Ensinck JW, Porte D, Jr (1991) Glucose stimulates and potentiates islet amyloid polypeptide secretion by the B-cell. Horm Metab Res 23: $577-580$

5. Ensinck JW, Laschansky EC, Vogel RE, Simonowitz DA, Roos BA, Francis BH (1989) Circulating prosomatostatinderived peptides. Differential responses to food ingestion. J Clin Invest 83: 1580-1589

6. Kuffert A, Stern JS, Curry DL (1988) Pancreatic hypersensitivity to glucose by young obese Zucker rats (fa/fa). Metabolism 37: 952-957

7. Kahn SE, Prigeon RL, McCulloch DK et al. (1993) Quantification of the relationship between insulin sensitivity and $\beta$ cell function in human subjects. Evidence for a hyperbolic function. Diabetes 42: 1663-1672

8. Nagamatsu S, Carroll RJ, Grodsky GM, Steiner DF (1990) Lack of islet amyloid polypeptide regulation of insulin biosynthesis or secretion in normal rat islets. Diabetes 39: 871874

9. Haegerstrand A, Dalsgaard CJ, Jonzon B, Larsson O, Nilsson J (1990) Calcitonin gene-related peptide stimulates proliferation of human endothelial cells. Proc Natl Acad Sci 87: 3299-3303

10. Kahn SE, Verchere CB, D'Alessio DA, Cook DL, Fujimoto WY (1993) Evidence for selective release of rodent islet amyloid polypeptide through the constitutive secretory pathway. Diabetologia 36: 570-573 